\title{
Performance and Emission Analysis of Waste Animal Fat Methyl Esters Blends on Naturally Aspirated Single Cylinder Engine
}

DOI : 10.36909/jer.ICCEMME.15833

Ashish Kumar Singh, Harveer Singh Pali*, and Mohd. Mohsin Khan

Mechanical Engineering Department, National Institute of Technology, Srinagar, Jammu \& Kashmir, India.

*Email: hspali@nitsri.ac.in; Corresponding Author.

\begin{abstract}
With emergent energy demands along growing concerns over health and ecological issues, have motivated consideration of biomasses derived alternative fuels, such as biodiesel for IC engines. In the current study transesterified waste animal fat was investigated for performance and emission characteristics and compared with mineral diesel. Experiments was performed on a single cylinder four stroke CI engine with constant injection pressure on Kirloskar TV1 having power $3.60 \mathrm{~kW} @ 1500 \mathrm{rpm}$. Using these constraints BTE and BSEC are computed. Exhaust emission behavior of such alternative fuels is vital in order to assess suitability for further utilization to compare these $\mathrm{uHC}, \mathrm{CO}, \mathrm{NO}_{\mathrm{x}}$ and smoke emission were also measured for all the test fuels. Emission reports indicate higher $\mathrm{NO}_{\mathrm{x}}$ and lesser $\mathrm{CO}$ emissions compared to mineral diesel. The characteristics found to be equivalent with ASTM Standards which is a favorable fuel requirement.
\end{abstract}

Key words: Biofuel, renewable Energy, Waste Animal Fat Methyl Ester.

\section{INTRODUCTION}

Energy is most substantial portion for any nation's frugality. With the day by day depletion of oil reserves and the new stringent environmental laws in force made the world moving towards a better, cleaner and safer option like renewable energy resources. In India renewable energy power generation is $90,399.11 \mathrm{MW}$ in 2020 which was $24 \%$ of the total power generation in 
the country (Annual Reports for New and Renewable Energy Sector, 2019-2020). On other hand India can possibly create vitality by sun powered, hydro, wind and bio-starting points yet their utilizations are constrained in India (Basic Indian Statistics Petroleum \& Natural Gas, 2019-20).

The major form goods transportation in India like more than $90 \%$ of trucks play on this and other than electricity the whole railway network plays on it. Thus these diesel engines are the back bone of our economy (Basic Statistics on Indian Petroleum \& Natural Gas, 2019-20). Diesel engines have a very significant task by which it acting a significant task in Indian economy (Frank Lujaji et. al. 2011). The consumption of crude oil during 2019-2020 is 201.9 million metric tons (IEA 2020). Indian Government spent 102 billion USD to imports crude oils from other countries in the year of 2019-2020 (All India / Region wise Power Generation Overview, 2020, Amar Deep et. al. 2018).

The expanding costs of oil coming about items due to exhaust oil saves have likewise set up an overwhelming undertaking before scientists to search for elective powers that is a lot of cleaner and efficient than the current day petroleum derived fuels, for example, diesel and gasoline (Frank Lujaji et. al. 2011). Diesel engines have colossal uses in India in the field of cultivating, ventures, transportation and furthermore in vitality creation territories. By which the diesel engine acting a significant job in Indian economy. Hence the current days the elective powers for the diesel engines are significant.

To address these above problems we have to find alternative methods to produce fuels .And subsequently we have made a good progress in the field of bio-origin fuels .Alcohol, jatropha, waste animal fat, waste frying oil, seeds, food grains, stables etc are the major players in bioorigin fuel which can contribute on our above ongoing problems (Pali Harveer Singh et. al. 2015, Y. Alhassan et. al. 2014).

Petroleum product makes our life easer but it has a huge impact on our society and environment. Biodiesel is a superior alternative fuel and it gets attentions for erstwhile. Both 
vegetable oils and animal fats whether edible and non-edible could be used to produce biodiesel but concerned food security restricts with the use of non-edible oil (Kumar N. et. al. 2015). In early years so many hard works has been done by many researchers to make biodiesel as a diesel engine fuel.

Biodiesel is clean consuming, sustainable substitution for diesel to be utilized in existing diesel engines deprived of adjustment; it is the country's locally created financially accessible progressed biofuel (Deep A. et. al. 2013). Biodiesel was mixed with diesel to bring much of the beneficial features to diesel equipment, with reduction in overall fuel cost (Vibhanshu V. et. al. 2014).

Biodiesel is a sheltered elective fuel to supplant conventional oil diesel. It has high lubricity, is a perfect consuming fuel and can be a fuel segment for use in existing, unmodified diesel engines. This implies no retrofits are vital when utilizing biodiesel fuel in any diesel controlled burning engine. It is the main elective fuel that offers such comfort (D.Y.C. Leung Y et. al. 2006, Zhang Y et. al. 2003).

Animal fats stay alluring feedstock for biodiesel on the grounds that their expense is considerably lower than vegetable oil. This is mostly in light of the fact that vegetable oil market is less constrained than animal fat market, since a great part of animal fat delivered in India isn't viewed as palatable by people.

Y. Zhang et al. 2003 analyzed alkali catalyzed process utilizing virgin oil and ensued that Waste oil can be utilized as the crude material. Anildo Cunha Jr et al. 2013 implemented RMS optimizations and produce high quality biodiesel under mild condition (30c). Dhiraj S et al. 2012 concluded use of animal fat biodiesel as properties improver or solvent. Metin Guru et al. 2010 considered Chicken fat biodiesel blend as an elective fuel in traditional CI engine with no significant Modification. Haq Nawaz Bhatti et al. 2008 bring into being sheep, chicken and lamb fat methyl ester using acid catalyst were more suitable in comparison to base catalyzed reactions. Michele Espinosa da Cunha et al. 2008 identified comparable characteristics of 
sheep biodiesel blends in CI engine without loss of efficiency. M. Kirubakaran et al. 2018 concluded that high quality biodiesel to be replaced with waste animal fat. Peter Adewale et al. 2015 reported lesser NOx outflow for animal fat biodiesel. Tashtoush et al. 2008 study the assessment and enhancement of change of waste animal fat into biodiesel and concluded compromise between response time and temperatures response culmination is the most basic fuel quality parameter.

Animal fat feedstock's can be made into top notch biodiesel that meets the ASTM particulars for biodiesel. Animal fats are high immersed which implies that the fat sets at a generally high temperature. Accordingly biodiesel produced using animal fat has a high cloud point. The high cloud purpose of the animal fat biodiesel doesn't have a lot of impact on the cloud purpose of the mix. In India the waste animal fats are best crude materials to made biodiesel in light of the fact that the fats are effectively be gather. WAFME biodiesel allows substituting the significant part of oil diesel which is utilized in compression ignition (CI) engine to accomplish the huge decrease

\section{METHODOLOGY}

Waste animal fat consists of mono carboxylic acids with trihydric alcohol glyceride. During heating free fatty acid content is improved by hydrolysis of receptive segments because of water from food. As per ASTM standard the density of waste animal fat oil was $0.880 \mathrm{~kg} / \mathrm{m}^{3}$ at temperature $40^{\circ} \mathrm{C}$. Similarly the kinematic viscosity $\left(40^{\circ} \mathrm{C}\right)$ and the flash point of the waste animal fat oil were $4.8 \mathrm{cSt}$ and $146^{\circ} \mathrm{C}$ respectively with 58 cetane number along with calorific value and plugging point were $39.60 \mathrm{MJ} / \mathrm{kg}$ and $0^{\circ} \mathrm{C}$ respectively.

To use the waste animal fat in a useful way it should be transesterified and converted into biodiesel ( Amar Deep et. al. 2018).

Blending process is done by blending 5\%,10\% and 20\% of WAFME biodiesel with neat diesel respectively. All the tests samples were kept in shut jugs for two weeks and routinely checked for the homogeneity and stage partition. 
Figure 1 shows test rig schematic diagram which is used to determine the performance and emissions characteristics in current investigation. In this figure there is a control panel which is used for RPM, temperature, voltage measurement. For the measurement of different emissions there is an emission analyzer and to measure the brake power an electrical dynamometer is used. To start this engine we used hand lever.

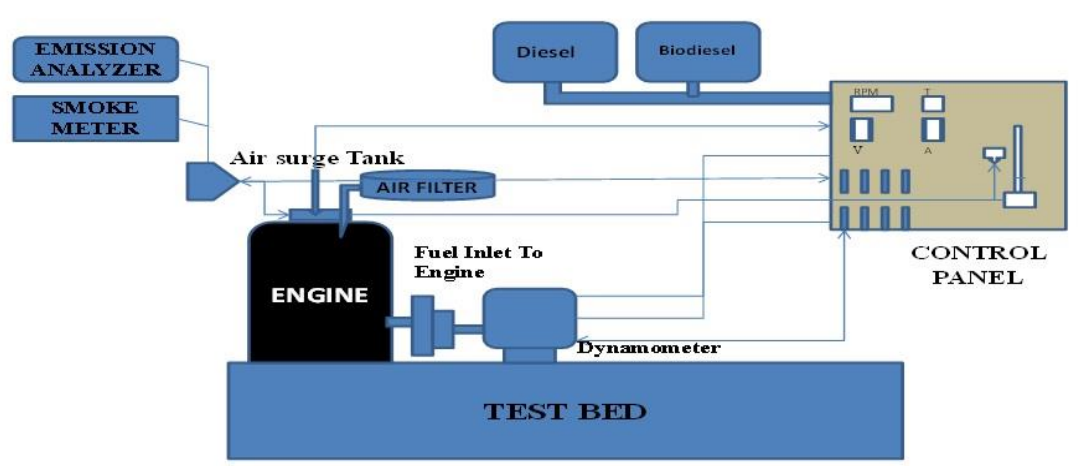

Figure 1 Test Rig Schematic Diagram.

For the evaluation of performance and emissions characteristics we used a diesel engine with some important specifications which was given in table 1.

Table 1 Diesel Engine Specification.

\begin{tabular}{|c|c|}
\hline Number of Cylinder & 1 \\
\hline Number of strokes & 4 \\
\hline Fuel & H.S Diesel \\
\hline Rated Power & $3.6 \mathrm{KW}, 1500 \mathrm{RPM}$ \\
\hline Cylinder Diameter & $87.5 \mathrm{~mm}$ \\
\hline Stroke length & $110 \mathrm{~mm}$ \\
\hline Connecting Rod Length & $234 \mathrm{~mm}$ \\
\hline Compression Ratio & 16.51 \\
\hline Orifice Diameter & $20 \mathrm{~mm}$ \\
\hline Dynamometer Arm Length & $185 \mathrm{~mm}$ \\
\hline
\end{tabular}

\section{PHYSICO-CHEMICAL PROPERTIES}

There is an overall after effect of physico-chemical properties of waste animal fat biodiesel and neat diesel mixes was made with neat diesel. In the table 2 the outcomes are summed up that is density, cetane number, calorific value and kinematic consistency. More noteworthy 
is the measure of waste animal fat biodiesel in perfect diesel lesser is the thickness, cetane number, calorific worth and kinematic consistency.

Table 2 Physico-Chemical Properties.

\begin{tabular}{|c|c|c|c|c|}
\hline FUEL & DENSITY $\left(\mathbf{g} / \mathbf{c m}^{\mathbf{3}}\right)$ & $\begin{array}{c}\text { CETANE } \\
\text { NO. }\end{array}$ & $\begin{array}{c}\text { CALORIFIC } \\
\text { VALUE } \\
\text { (MJ/kg) }\end{array}$ & $\begin{array}{c}\text { KINEMATIC } \\
\text { VISCOSITY(cSt) }\end{array}$ \\
\hline D100 & 0.831 & 48 & 43.3 & 3.5 \\
\hline WAFME & 0.899 & 56 & 40.7 & 5.42 \\
\hline WAFME5 & 0.8563 & 51 & 43.1 & 3.574 \\
\hline WAFME10 & 0.8655 & 52 & 42.9 & 3.642 \\
\hline WAFME20 & 0.8749 & 53 & 42.2 & 3.880 \\
\hline
\end{tabular}

\section{RESULT}

On a diesel engine the current investigation was done to assess the performance and emission qualities fueled with waste animal fat biodiesel blends which is the significant target of the examination.

\section{BRAKE THERMAL EFFICIENCY}

A comparison between the BTE of the diesel engine with the bmep for the diverse blends which seen in figure 2. As per investigation results we get than there are some increment in the BTE of diesel engine with the increase in the blending. This is due to raise in the viscosity with increasing blending percentage. Also decreasing heating value tends to decrement of the brake thermal efficiency at 20 percent blending. The results are in agreement with Deep A et al.2015.

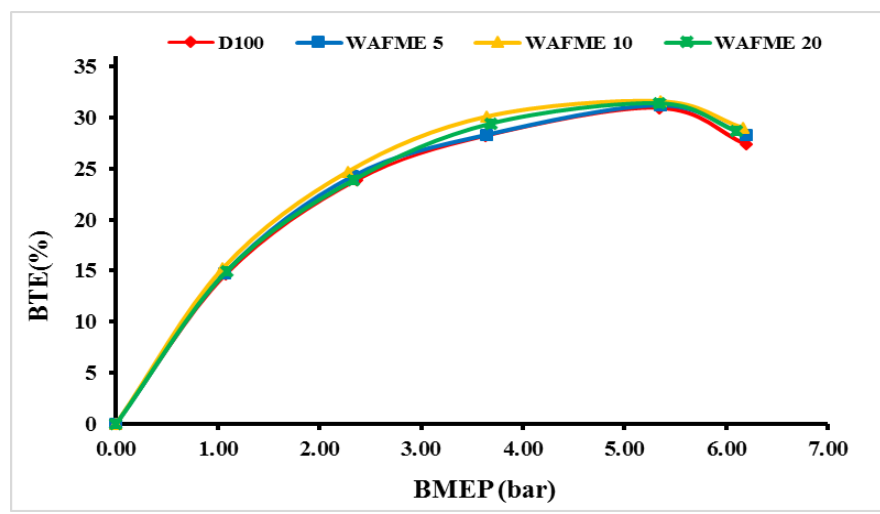


Figure 2 BTE vs. BMEP

For the blends the maximum thermal is observed in the engine WAFME5, WAFME10, WAFME20 and D100 are $29.4 \%, 30.9 \%, 29.9 \%$ and $30.7 \%$ at $80 \%$ of load.

\section{BRAKE SPECIFIC ENERGY CONSUMPTION}

There was a superior boundary for the examination of various mixes of waste animal fat biodiesel and neat diesel that is brake specific energy consumption since density and calorific estimation of both are extraordinary. Figure 3 shows that the BSEC reduction with the increment in BMEP. WAFME10 blend of biodiesel has the highest BSEC due to high viscosity and low calorific values..

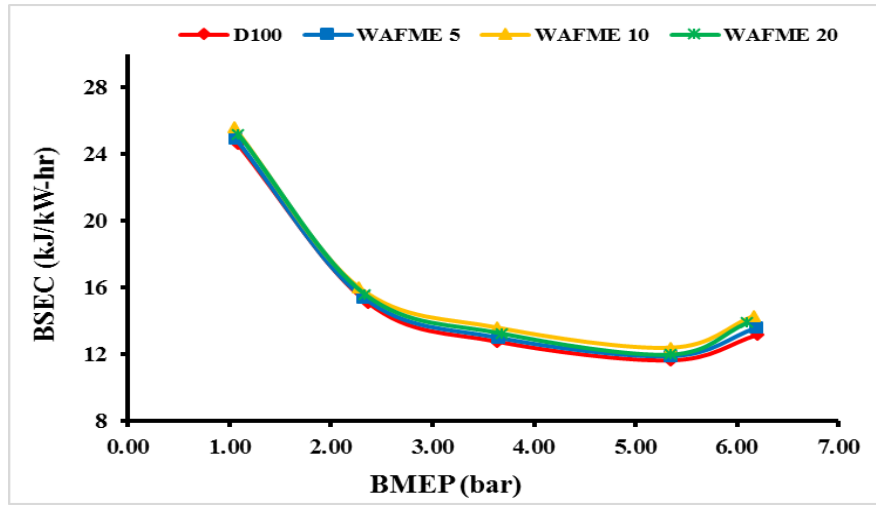

Figure 3 BSEC vs. BMEP

\section{CABON MONOXIDE EMISSIONS}

From figure 4 a decreased in $\mathrm{CO}$ emissions is observed due to the addition of the waste animal fat biodiesel in neat diesel. There is a decreased in $\mathrm{CO}$ for biodiesel fuel at higher loads. There is a decrement in the carbon monoxide due to decrement in viscosity and density of the fuel. And also there is a raise in volatility due to decreased in the density of the fuel. 


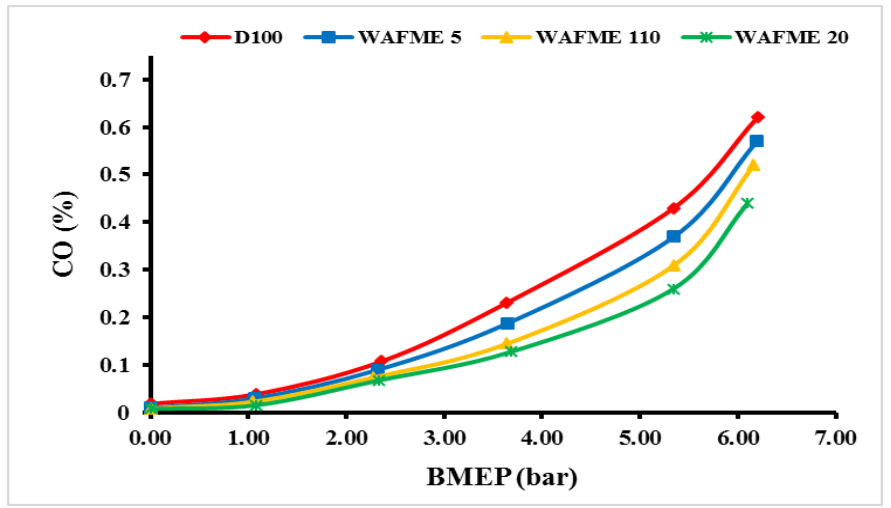

Figure 4 CO vs. BMEP

\section{OXIDES OF NITROGEN EMISSIONS}

Oxides of Nitrogen emissions gradually increases with BMEp. From figure 5 it is cleared that when the blending of biodiesel increase the $\mathrm{NO}_{\mathrm{X}}$ emissions are also increases. The lower flash point and higher cetane number of biodiesel leads to proper combustion leading to formation of NOx. It is cleared that for $\mathrm{NO}_{\mathrm{X}}$ emissions the combustion temperature and the load variations are the major factors.

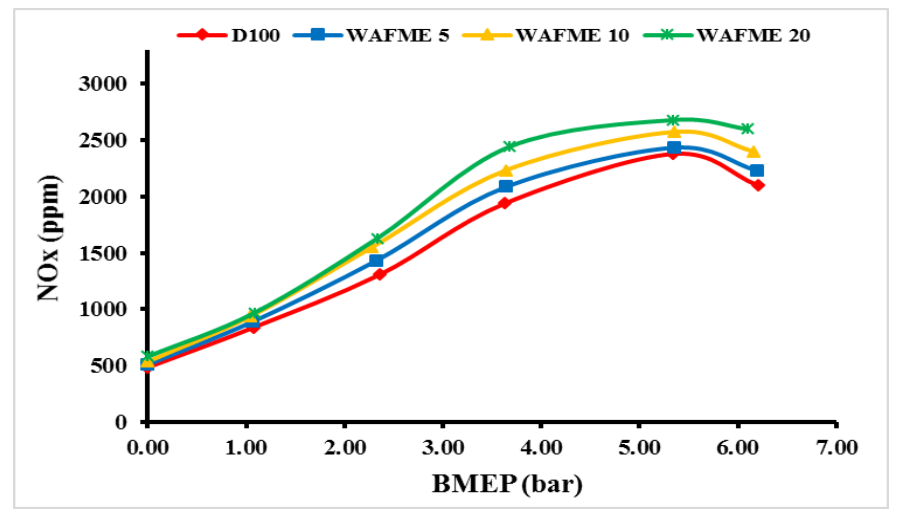

Figure $5 \mathrm{NO}_{x}$ vs. BMEP

\section{HYDRO CARBON EMISSIONS}

In this figure, for the waste animal fat biodiesel there are some variations in the unburnt

hydrocarbons. In this study it is cleared that when the blending percentage of waste animal biodiesel increases there is continuous decrease in $\mathrm{HC}$ emissions. The methyl ester addition contributed to stable combustion leads to decrease in $\mathrm{HC}$ at higher load as the engine runs at a slightly rich mixture the $\mathrm{HC}$ emission are found increasing with load. 


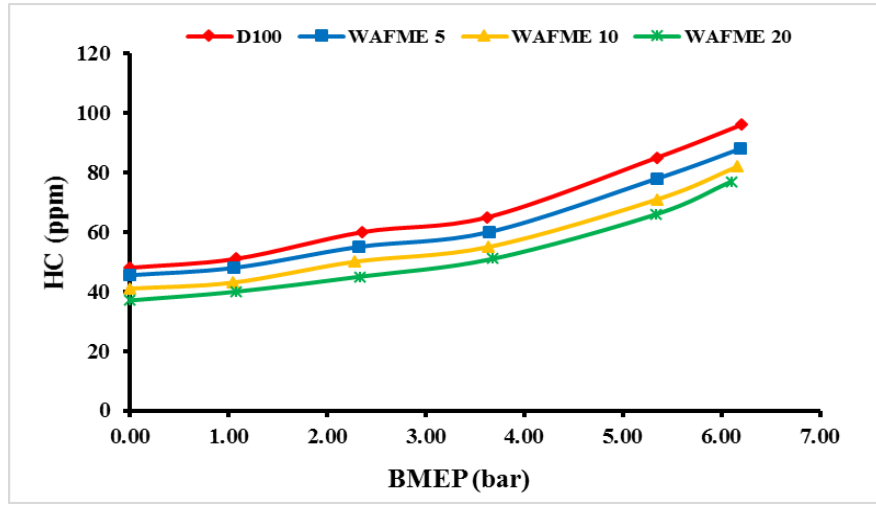

Figure 6 HC vs. BMEP

\section{SMOKE OPACITY}

From figure 7 it is found that the neat diesel under all load condition gives the maximum content in smoke level and the minimum smoke content is found in the WAFME20 blend. Availability of oxygen in biodiesel resulted in mixing of air and fuel leading to formation of diffusive flame. At higher load due to improper atomization of fuel resulting in higher sauter mean diameter of fuel droplet increasing ignition delay and cause high smoke formation.

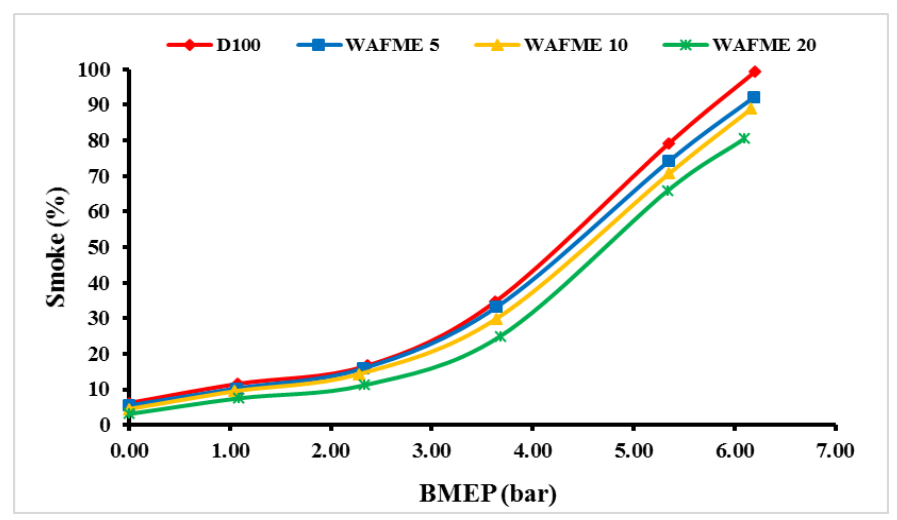

Figure 7 SMOKE OPACITY vs. BMEP

\section{CONCLUSION}

The outcomes of this examination demonstrated that the waste animal fat biodiesel is a manageable fuel for building nations like India.

- The maximum BTE was obtained with WAFME 10 blend. The brake thermal efficiency of WAFME 5 and WAFME 20 blend was higher in comparison to neat diesel fuel but 
lower as compared to WAFME 10 blend. Thus it shows that the break thermal efficiency increased on blending.

- The brake specific energy consumption of WAFME 5 and WAFME 20 blend was maximum at low load but reduces at full load in comparison to WAFME 10.

- The minimum Carbon monoxide and hydrocarbon emissions were observed with the WAFME 20 blend.

- The $\mathrm{NO}_{\mathrm{X}}$ emissions observed with WAFME 5 and WAFME 10 were higher as compared to neat diesel fuel.

After the current examination unmistakably waste animal fat biodiesel is expected as elective fuel for Diesel engines as per National Biodiesel Mission of India and abundance availability of animal fat feedstock.

\section{REFERENCES}

Annual Reports for New and Renewable Energy Sector, 2019-2020, Ministry of New and Renewable Energy, Government of India.

Basic Statistics on Indian Petroleum \& Natural Gas, 2019-20, Ministry of Petroleum \& Natural Gas, Government of India.

Frank Lujaji, Lukács Kristóf, Akos Bereczky, Makame Mbarawa, 2011, Experimental investigation of fuel properties, engine performance, combustion and emissions of blends containing croton oil, butanol, and diesel on a CI engine, Fuel, Volume 90, Issue 2,Pages

505-510, ISSN 0016-2361,https://doi.org/10.1016/j.fuel.2010.10.004.

BP Statistical Review 2020, World Energy.

IEA, World Energy Statistics 2020.

All India / Region wise Power Generation Overview, 2020, Central Electricity Authority, Ministry of Power, Govt. of India. 
Amar Deep, Rakesh Kumar \& Naveen Kumar, 2018, Studies on the use of orange peel oil and ethanol in an unmodified agricultural diesel engine, Energy Sources, Part A: Recovery, Utilization, and Environmental Effects, https://doi.org/10.1080/15567036.2018.1549160.

Pali Harveer Singh Kumar Naveen, Alhassan Yahaya, Deep Amar, 2015, Process Optimization of Biodiesel Production from Sal Seed Oil using Response Surface Methodology [RSM] and Diesel, SAE International Paper 2015-01-1297, doi: https://doi.org/10.4271/2015-01-1297.

Y. Alhassan, N. Kumar, I.M. Bugaje, H.S. Pali, P. Kathkar, 2014, Co-solvents transesterification of cotton seed oil into biodiesel: Effects of reaction conditions on quality of fatty acids methyl esters, Energy Conversion and Management, Volume 84, Pages 640648, ISSN 0196-8904, https://doi.org/10.1016/j.enconman.2014.04.080.

Kumar, N., Bansal, S., and Pali, H.,2015, Blending of Higher Alcohols with Vegetable Oil Based Fuels for Use in Compression Ignition Engine, SAE Technical Paper 2015-01-0958, https://doi.org/10.4271/2015-01-0958.

Deep, A., Singh, A., Vibhanshu, V., Khandelwal, A. et al., 2013, Experimental Investigation of Orange Peel Oil Methyl Ester on Single Cylinder Diesel Engine, SAE Technical Paper 2013-24-0171, https://doi.org/10.4271/2013-24-0171.

Vibhanshu, V., Karnwal, A., Deep, A., and Kumar, N., 2014, Performance, Emission and

Combustion, Analysis of Diesel Engine Fueled with Blends of Mahua Oil Methyl Ester and Diesel, SAE Technical Paper 2014-01-2651, https://doi.org/10.4271/2014-01-2651.

D.Y.C. Leung, Y. Guo, 2006, Transesterification of neat and used frying oil: Optimization for biodiesel production, Fuel Processing Technology, Volume 87, Issue 10, Pages 883890, ISSN 0378-3820, https://doi.org/10.1016/j.fuproc.2006.06.003.

Zhang Y, Dubé MA, McLean DD, Kates M., 2003, Biodiesel production from waste cooking 
oil: 2. Economic assessment and sensitivity analysis. Bioresour Technol, 90(3):229-40. doi: 10.1016/s0960-8524(03)00150-0.

Anildo Cunha Jr, Vivian Feddern, Marina C. De Prá, Martha M. Higarashi, Paulo G. de Abreu, Arlei Coldebella,2013, Synthesis and characterization of ethylic biodiesel from animal fat wastes, Fuel, Volume 105, Pages 228-234, ISSN 0016-2361, https://doi.org/10.1016/j.fuel.2012.06.020.

Darunde Dhiraj S, Prof. Deshmukh Mangesh M., 2012, Biodiesel Production From Animal

Fats And Its Impact On The Diesel Engine With Ethanol-Diesel Blends: A Review, International Journal of Emerging Technology and Advanced Engineering, Volume 2, Issue 10 , ISSN 2250-2459.

Gürü, Metin \& Koca, Atilla \& Can, Özer \& Çınar, Can \& Şahin, Fatih, 2010., Biodiesel production from waste chicken fat based sources and evaluation with $\mathrm{Mg}$ based additive in a diesel engine, Renewable Energy, Elsevier, vol. 35(3), pages 637-643, doi 10.1016/j.renene.2009.08.01

Haq Nawaz Bhatti; Muhammad Asif Hanif; Umar Faruq; Munir Ahmad Sheikh. 2008, Acid and Base Catalyzed Transesterification of Animal Fats to Biodiesel, Iran. J. Chem. Chem. Eng. Vol. 27, No. 4, doi: 10.30492/IJCCE.2008.6946.

Haq Nawaz Bhatti, Muhammad Asif Hanif, Mohammad Qasim, Ata-ur-Rehman, 2008, Biodiesel production from waste tallow, Fuel, Volume 87, Issues 13-14,Pages 2961-2966, ISSN 0016-2361, https://doi.org/10.1016/j.fuel.2008.04.016.

Michele Espinosa da Cunha, Laiza Canielas Krause, Maria Silvana Aranda Moraes, Candice Schmitt Faccini, Rosângela Assis Jacques, Suelen Rodrigues Almeida, Maria Regina Alves Rodrigues, Elina Bastos Caramão, 2008, Beef tallow biodiesel produced in a pilot scale, energy Fuels 2008, 22, 3, 1949-1954, https://doi.org/10.1021/ef7006535. 
M. Kirubakaran, V. Arul Mozhi Selvan, 2018, A comprehensive review of low cost biodiesel production from waste chicken fat, Renewable and Sustainable Energy Reviews, Volume $\quad$ 82, Part 1,Pages 390-401, ISSN 1364-0321, https://doi.org/10.1016/j.rser.2017.09.039.

Adewale Peter, Dumont Marie-Josée \& Ngadi, Michael, 2015, Recent trends of biodiesel production from animal fat wastes and associated production techniques, Renewable and Sustainable Energy Reviews, Elsevier, vol. 45(C), pages 574-588, doi:

10.1016/j.rser.2015.02.039

Tashtoush Ghassan M, Al-WidyanMohamad I, Al-Jarrah Mohammad M, 2008, Experimental study on evaluation and optimization of conversion of waste animal fat into biodiesel. Energy Conversion and Management, 45:2697-711, ISSN: 0196-8904,

Deep, A., Kumar, N., Kumar, M., Singh, A. et al, 2015, Performance and Emission Studies of Diesel Engine Fuelled with Orange Peel Oil and N-Butanol Alcohol Blends," SAE Technical Paper 2015-26-0049, doi:10.4271/2015-26-0049. 